\title{
Article \\ Differential Seed Germination Responses of Tomato Landraces to Temperature under Climate Change Scenarios
}

\author{
Naeimeh Sousaraei ${ }^{1}$, Benjamin Torabi ${ }^{2}$, Elias Soltani ${ }^{3, * \mathbb{C}}$, Kambiz Mashayekhi $^{1}$ and Joaquín Medina ${ }^{4}(\mathbb{D}$ \\ 1 Department of Horticultural Sciences, Gorgan University of Agricultural Sciences and Natural Resources, \\ Gorgan 49138-15749, Iran; nsousaraei@gmail.com (N.S.); mashayekhi@gau.ac.ir (K.M.) \\ 2 Department of Agronomy, Gorgan University of Agricultural Sciences and Natural Resources, \\ Gorgan 49138-15749, Iran; ben_torabi@yahoo.com \\ 3 Department of Agronomy and Plant Breeding Sciences, Abureyhan Campus, University of Tehran, \\ Teheran 33916-53755, Iran \\ 4 Instituto Nacional de Investigación y Tecnología Agraria y Alimentaria (INIA)-CSIC, 28223 Madrid, Spain; \\ medina.joaquin@inia.es \\ * Correspondence: elias.soltani@ut.ac.ir
}

check for updates

Citation: Sousaraei, N.; Torabi, B.; Soltani, E.; Mashayekhi, K.; Medina, J. Differential Seed Germination

Responses of Tomato Landraces to Temperature under Climate Change Scenarios. Seeds 2022, 1, 36-48. https://doi.org/10.3390/seeds1010005 Academic Editor: Valeria Cavallaro

Received: 11 January 2022

Accepted: 4 March 2022

Published: 7 March 2022

Publisher's Note: MDPI stays neutral with regard to jurisdictional claims in published maps and institutional affiliations.

Copyright: (C) 2022 by the authors. Licensee MDPI, Basel, Switzerland. This article is an open access article distributed under the terms and conditions of the Creative Commons Attribution (CC BY) license (https:// creativecommons.org/licenses/by/ $4.0 /)$.

\begin{abstract}
This study aims to quantify the seed germination response of six tomato landraces to temperature; predict future climate changes relative to the baseline period (1980-2009) for studied locations in the courses of near-term (2010-2039) and mid-term (2040-2069) under two representative concentration pathways (RCP 4.5 and 8.5 ); assess the impact of future climate change on the final germination percentage (FGP) and time to reach $50 \%$ germination (D50) in the studied landraces. The results show that FGP is zero at $10{ }^{\circ} \mathrm{C}$, reaches the highest value at $15-35^{\circ} \mathrm{C}$, and ceases at $36-40{ }^{\circ} \mathrm{C}$ for all landraces. The results also demonstrate that the temperature increment is $0.8-1.3^{\circ} \mathrm{C}$ and $1.5-2.7^{\circ} \mathrm{C}$ in the near- and mid-term, respectively, under RCP 4.5; further, this increment is $0.9-1.9^{\circ} \mathrm{C}$ for the near-term and $2.3-3.4^{\circ} \mathrm{C}$ for the mid-term under RCP 8.5. It estimates that the D50 takes 2.5 to 3.8 days among the locations in the baseline course. In the near term, the D50 would be 2.2 to 3.4 days under RCP 4.5 and 2.1 to 3.3 days under RCP 8.5. For the mid-term, the D50 would be projected between 1.9 and 2.9 days under RCP 4.5 and 1.8 to 2.7 days under RCP 8.5. The FGP increases up to $19.5 \%$ for Gorgan and $21.3 \%$ for Varamin under climatic scenarios relative to baseline, and it will not change in the future climate for other landraces. In conclusion, global warming can result in rapid, uniform, and complete germination in different tomato landraces.
\end{abstract}

Keywords: cardinal temperature; climate alternations; final germination percentage; future climate; germination rate

\section{Introduction}

In the 21st century, the average global temperature is predicted to elevate from 2 to $4.5^{\circ} \mathrm{C}$. According to IPCC-2014 (http:/ / www.ipcc.ch/ accessed on 6 January 2022), the earth is expected to experience the most warming period between the 19th and the 21st centuries [1]. The studies demonstrated that climate change is causing an increase in mean temperature and precipitation variability in different regions of the world [2,3]. Climate change will misadjust the interactions between climate and biology, from the enzymatic process to ecological responses [4]. Climate change has significant effects on all stages of plant development, from seed germination to maturity $[5,6]$.

The effects of ongoing climate change on plant yield have been extensively studied $[7,8]$. For instance, climate change from 1980 to 2008 has resulted in reduced global production of maize by $3.8 \%$ and wheat by $5.5 \%$ compared with a counterfactual without climate change [9]. A recent meta-analysis-based on the published simulation studies on climate change impacts on yields and adaptation-showed that without adaptation, there will be 
losses in production for wheat, rice, and maize in both temperate and tropical regions by $2{ }^{\circ} \mathrm{C}$ of local warming [10].

Climate thoroughly controls key processes such as plant regeneration, as is exemplified by the thermal regulation of seed germination [11]. Seed germination and seedling emergence are critical phases of a crop cycle that affect the success or failure of any crop establishment [12]. Successful seed germination occurs in response to a specific combination of environmental factors such as temperature, moisture, and light [13]. Soil moisture in most areas is not limiting for seed germination due to pre-sowing irrigation or adequate autumn, winter, and early spring precipitation, while the temperature can be a determinative factor $[14,15]$.

Tomato (Solanum lycopersicum L.), as a warm-season plant, is usually grown in the greenhouse (indirect seeding), but it can also be cultivated in the open field (direct seeding) by suitable sowing date in the spring after the danger of frost has passed [16]. Tomatoes will be properly grown if the daytime temperature is between 18 and $30^{\circ} \mathrm{C}$ [17]. The temperature can determine seed germination and subsequent seedling establishment and crop growth status and thus is a vital step in crop growth [13]. Rapid, uniform, and complete germination is leading to improve seedling establishment and rapid canopy closure. This results in increasing intercepted radiation and plant growth rate and consequently maximizing plant yield $[18,19]$. Temperature drives local adaptation $[20,21]$ and phenotypic plasticity [22-24] in germination traits, as well as the physiological processes of dormancy loss [15,25] and germination elicitation [26]. Local populations or landraces have developed over time through adaptation to their natural and maternal growing environment and originated by adaptive responses to local habitats [27]. So, in seasonal climates, germination traits of landraces coincide with annual temperature cycles to ensure that seed emergence and seedling establishment occur in the most favorable season [13]. Given the significance of seed germination in the life history of a plant, it is not surprising that its timing is a central scenario for natural selection [28].

Although germination response to environmental factors has been widely investigated for different species [29-31], knowledge of seed germination response of tomato landraces and their geographical distribution is scarce under future climate conditions. Accordingly, the aims of this study are: (1) quantify the response of seed germination, time to reach $50 \%$ germination and germination rate of six tomato landraces collected from different climatic zones of Iran to different temperature conditions, (2) prediction of future climate change relative to baseline period for studied landraces (locations) in the courses of near-term (2010-2039) and mid-term (2040-2069) with the use of Global Circulation Models (GCM) of HadGEM2-ES (HadGEM) and IPSL-CM5A-MR (IPSL) from the Coupled Model Intercomparison Project Phase 5 (CMIP5) for two Representative Concentration Pathways (RCP 4.5 and RCP 8.5) of the International Panel on Climate Change (IPCC) and (3) assessment of the impact of future climate changes on the final germination percentage and time to reach $50 \%$ germination in the studied landraces.

\section{Materials and methods}

\subsection{Seed Collection}

Seeds of six tomato landraces were collected from six different locations (Rasht, Sari, Gorgan, Esfarayen, Varamin, and Shiraz) in 2017, which represent the different geographical regions in Iran (Table 1). All seeds were kept in cold storage to maintain seed quality before testing. 
Table 1. Geographical and meteorological characterizations of the origin of tomato landraces used in this experiment.

\begin{tabular}{ccccc}
\hline Location & $\begin{array}{c}\text { Latitude and } \\
\text { Longitude }\end{array}$ & $\begin{array}{c}\text { Average Annual } \\
\text { Temperature } \\
\left({ }^{\circ} \mathbf{C}\right)\end{array}$ & $\begin{array}{c}\text { Average Annual } \\
\text { Rainfall (mm) }\end{array}$ & $\begin{array}{c}\text { Above Sea } \\
\text { Level (m) }\end{array}$ \\
\hline Rasht & $37.16^{\circ} \mathrm{N}, 49.36^{\circ} \mathrm{E}$ & 16.5 & 1359 & 5 \\
Gorgan & $36.83^{\circ} \mathrm{N}, 54.48^{\circ} \mathrm{E}$ & 18.4 & 675 & 155 \\
Esfarayen & $37.73^{\circ} \mathrm{N}, 57.5^{\circ} \mathrm{E}$ & 16.5 & 212 & 1249 \\
Sari & $36.4^{\circ} \mathrm{N}, 53.5^{\circ} \mathrm{E}$ & 18.2 & 789 & 32 \\
Varamin & $35.32^{\circ} \mathrm{N}, 51.64^{\circ} \mathrm{E}$ & 18 & 156 & 918 \\
Shiraz & $29.61^{\circ} \mathrm{N}, 52.54^{\circ} \mathrm{E}$ & 18.4 & 337 & 1486 \\
\hline
\end{tabular}

\subsection{Study Area}

Rasht, Sari, and Gorgan are located in the north of Iran, between the northern slopes of the Alborz Mountains and the southern coast of the Caspian Sea. Gorgan has a Mediterranean climate (Köppen climate classification: Csa), with warm and sub-humid summers and cool and rainy winters. Rasht and Sari have a humid subtropical climate (Cfa), with warm and humid summers and cool and rainy winters. Esfarayen is located in the northeastern of Iran. It is mountainous in the north and northeast and plain in the south and center. The Köppen climate classification for Esfarayen's climate is Mediterranean (Csa), with hot and dry summers and relatively mild winter. Varamin is located on the northwest edge of the central desert of Iran. According to the Köppen Climate Classification, Varamin's climate is a hot semi-arid climate (Bsh). This climate tends to have hot, sometimes extremely hot, summers and warm to cool winters, with some to minimal precipitation. Shiraz is located in the south of Iran. It is built in a green plain at the foot of the Zagros Mountains. Shiraz's climate is overall classed as a hot semi-arid climate (BSk). Summers are hot, arid, and clear, and the winters are cool and semi-arid.

\subsection{Germination Tests}

For each treatment, 150 seeds in three replicates of 50 seeds were placed on a double layer of absorbent filter paper in $10 \mathrm{~cm}$ Petri dishes and moistened with $10 \mathrm{~mL}$ distilled water. Seeds of each landrace were germinated in an incubator (model ICP-600, Memmert, Germany) at seven temperatures $\left(10,15,20,25,30,35\right.$, and $\left.40{ }^{\circ} \mathrm{C}\right)$. Seed germination progress was monitored at every $8-12 \mathrm{~h}$ intervals over a 7 - to 14 -day period. Seeds with radicles $2 \mathrm{~mm}$ or longer were considered germinated seeds. During the germination process, germinated seeds were counted and removed from Petri dishes.

The final germination percentage (FGP) was calculated for each temperature and replicated by dividing the total number of germinated seeds by the total number of seeds tested.

The dent-like function was used to describe the response of germination percentage to temperature. The function was described as follows [32]:

$$
\begin{gathered}
\text { FGP }=\left(T-T_{b}\right) /\left(T_{o 1}-T_{b}\right) \text { if } T_{b}<T<T_{o 1} \\
\text { FGP }=\left(T_{c}-T\right) /\left(T_{c}-T_{o 2}\right) \text { if } T_{o 2}<T<T_{c} \\
\text { FGP }=1 \text { if } T_{o 1} \leq T \leq T_{o 2} \\
\text { FGP }=0 \text { if } T \leq T_{b} \text { or } T \geq T_{c}
\end{gathered}
$$

where $T$ is the germination temperature, $T_{b}$ the base temperature, $T_{o}$ the optimum temperature, $T_{o 1}$ the lower optimum temperature, $T_{o 2}$ the upper optimum temperature, $T_{\mathcal{C}}$ the ceiling temperature.

Estimates of the time required to $50 \%$ of seed germination (D50) in each temperature and replicate were interpolated from the progress of germination (\%) versus time (hours) 
curve. To quantify the response of germination rate (R50; the inverse of D50) to temperature, the following segmented model was used [14]:

$$
\begin{aligned}
\text { R50 }= & \left(T-T_{b}\right) /\left(T_{o}-T_{b}\right) \text { if } T_{b}<T \leq T_{o} \\
\text { R50 }= & \left(T_{c}-T\right) /\left(T_{c}-T_{o}\right) \text { if } T_{o} \leq T<T_{\mathcal{c}} \\
& \text { R50 }=0 \text { if } T \leq T_{b} \text { or } T \geq T_{\mathcal{c}}
\end{aligned}
$$

where $T$ is the germination temperature, $T_{b}, T_{o}$ and $T_{c}$ are the base, optimum and ceiling temperatures for germination rate, respectively.

Thermal time (TT) in terms of ${ }^{\circ} \mathrm{C} \mathrm{d}^{-1}$ was calculated as follows:

$$
\mathrm{TT}=\left[\left(T_{o}-T_{b}\right) \times \mathrm{D} 50\right] / 24
$$

Data obtained from the experiments were first subjected to analysis of variance. The function parameters were estimated by the least-squares method using the non-linear (NLIN) regression procedure in SAS (SAS Institute Inc., Cary, NC, USA, 2013). Means of treatments and estimated parameters were compared using the standard error $( \pm 2 \mathrm{SE})$ at $5 \%$ level of probability.

\subsection{Future Climate Projection}

The baseline weather data (1980-2009), including daily maximum temperature (Tmax, ${ }^{\circ} \mathrm{C}$ ) and minimum temperature $\left(\mathrm{Tmin},{ }^{\circ} \mathrm{C}\right)$, were obtained from the synoptic meteorological station of studied locations (Rasht, Sari, Gorgan, Esfarayen, Varamin, and Shiraz). Quality control of weather data was performed using the WeatherMan program in the DSSAT model [33].

Future climates, including courses of near-term (2010-2039) and mid-term (20402069) were predicted with the use of Global Circulation Models (GCM) of HadGEM2-ES (HadGEM) and IPSL-CM5A-MR (IPSL) from the Coupled Model Intercomparison Project Phase 5 (CMIP5) for two Representative Concentration Pathways (RCP 4.5 and RCP 8.5) of the International Panel on Climate Change (IPCC) on a large scale [34,35]. The RCPs differ from each other in the assumptions of population, economic growth, energy consumption, and sources, and land use [36]. The RCP 4.5 is a medium pathway that stabilizes the radiative forcing at $4.5 \mathrm{w} . \mathrm{m}^{-2}$ by 2100 without overshoot [37], while RCP 8.5 assumes a rising Greenhouse Gases (GHG) pathway in absence of climate change policies [38].

The GCMs projections were downscaled and calculated via the delta method. For temperature projection in a given weather station, the delta method adds the differences between simulated current and future temperature from the GCM (HadGEM or IPSL) to the observed temperature of that station. Delta method scripts were run in " $R$ " to develop future climate scenarios by using scripts of the delta method [39-41].

\subsection{Assessing the Current and Future Temperature on Germination}

The survey investigations showed that the tomato is sowed when the air temperature under plastic cover is $20^{\circ} \mathrm{C}$ which coincided with DOY (day of year) of 69 to 139 for Esfarayen, 50 to 120 for Gorgan, 56 to 132 for Rasht, 70 to 110 for Sari, 65 to 99 for Shiraz and 55 to 101 for Varamin during a 30-year baseline and future periods. Finally, the mean temperature of the sowing period was calculated for the baseline, near-term and mid-term periods under both RCPs.

In order to protect the germinated seeds against the risk of early cold in direct tomato cultivation, the seeds are planted under a plastic cover, and it is removed after eliminating the risk of cold in 3- to 4-leaf stage. Regarding changing temperature under the plastic cover compared with the air temperature, a power relationship was used to estimate the temperature under the plastic cover $(\mathrm{y})$ through air mean temperature of the baseline period and near and mid-term periods under both RCP 4.5 and RCP $8.5(\mathrm{x})$ as below [42]:

$$
y=3.0378 x^{0.7042}
$$


Consequently, using the results obtained in Equations (1) and (2) for tomato landraces, the germination responses against mean temperature under the plastic cover of baseline and future periods were considered.

\section{Results}

\subsection{Final Germination Percentage}

Final germination percentage (FGP) was significantly affected by landrace $(\mathrm{F}=46.238$, $p<0.001)$, temperature $(\mathrm{F}=128.205, p<0.001)$ and their interactions $(\mathrm{F}=15.680, p<0.001)$. For each landrace, FGP increased with increasing temperature to reach the highest value (more than 90\%) under a given temperature range and then decreased with increasing temperature (Figure 1; Table 2). The germination temperatures where FGP reached the highest values varied among the landraces. For all landraces, germination was started above $10^{\circ} \mathrm{C}$, reached the highest value at $15-30^{\circ} \mathrm{C}$ for Esfarayen, Rasht and Sari landraces, $15-32{ }^{\circ} \mathrm{C}$ for Shiraz landrace, $20-31^{\circ} \mathrm{C}$ for Gorgan landrace, and $20-35^{\circ} \mathrm{C}$ for Varamin landrace, and ceased at $36^{\circ} \mathrm{C}$ for Esfarayen, and Rasht landraces, $37^{\circ} \mathrm{C}$ for Sari and Shiraz landraces and $40^{\circ} \mathrm{C}$ for Gorgan and Varamin landraces (Figure 1).
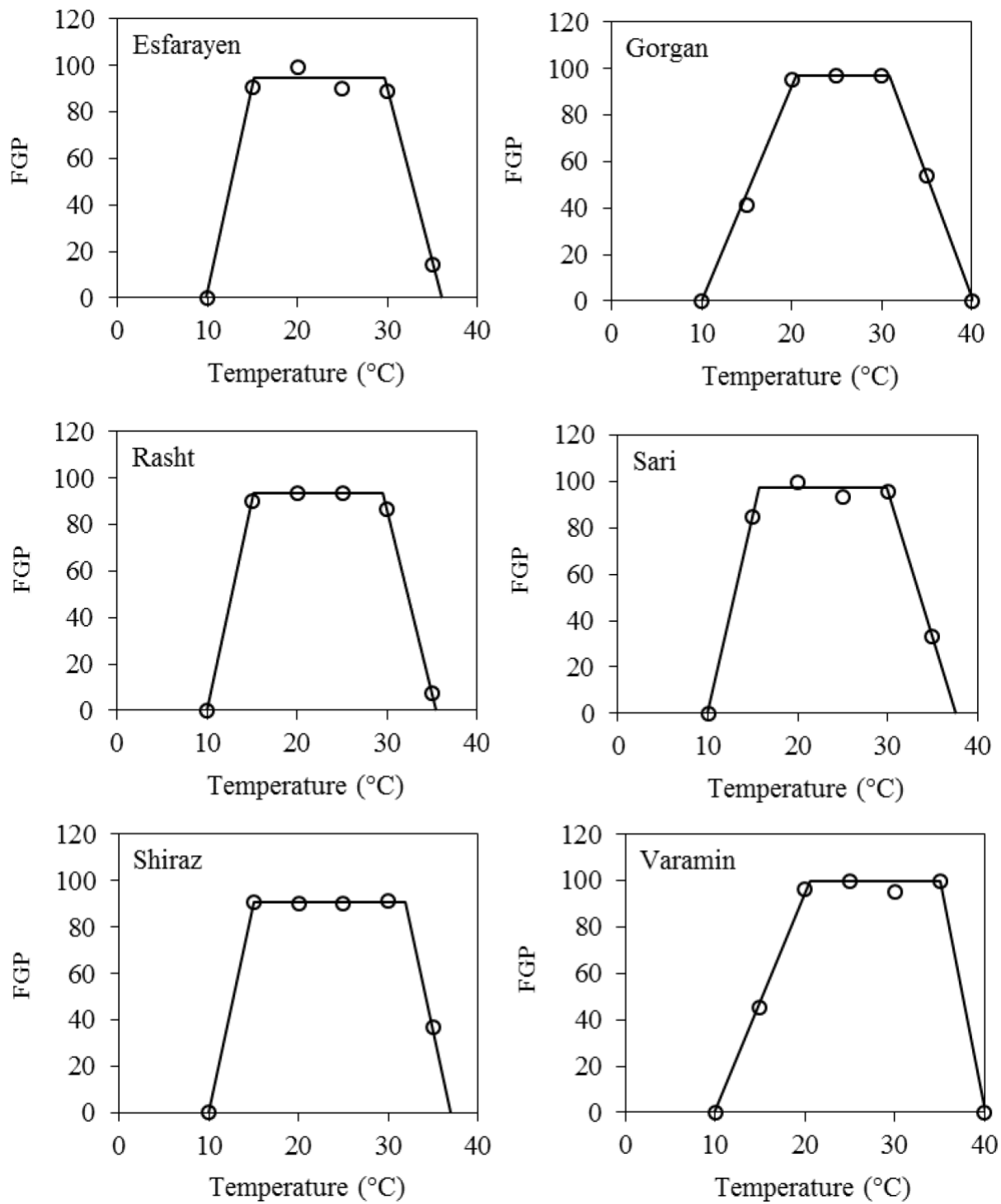

Figure 1. Relations between the final germination percentage (FGP) and temperature for six tomato landraces (Esfarayen, Gorgan, Rasht, Sari, Shiraz, and Varamin). The lines indicate the drawn dent-like function based on estimated function parameters, shown in Table 2. 
Table 2. Estimates $( \pm \mathrm{SE})$ of base temperature $\left(T_{b},{ }^{\circ} \mathrm{C}\right)$, optimum temperature $\left(T_{o 1}\right.$ and $\left.T_{o 2},{ }^{\circ} \mathrm{C}\right)$ and ceiling temperature $\left(T_{c},{ }^{\circ} \mathrm{C}\right)$ for germination of six tomato landraces using dent-like function.

\begin{tabular}{ccccc}
\hline Landrace & $\boldsymbol{T}_{\boldsymbol{b}} \pm \mathbf{S E}$ & $\boldsymbol{T}_{\boldsymbol{o} \mathbf{1}} \pm \mathbf{S E}$ & $\boldsymbol{T}_{\boldsymbol{o} \mathbf{2}} \pm \mathbf{S E}$ & $\boldsymbol{T}_{\boldsymbol{c}} \pm \mathbf{S E}$ \\
\hline Esfarayen & $9.9 \pm 0.21$ & $15.2 \pm 0.22$ & $29.6 \pm 0.27$ & $36 \pm 0.20$ \\
Gorgan & $10 \pm 0.34$ & $20.5 \pm 0.37$ & $30.8 \pm 0.68$ & $40.2 \pm 0.35$ \\
Rasht & $10 \pm 0.06$ & $15.2 \pm 0.08$ & $29.5 \pm 0.09$ & $35.5 \pm 0.06$ \\
Sari & $9.9 \pm 0.05$ & $15.7 \pm 0.05$ & $29.9 \pm 0.05$ & $37.6 \pm 0.10$ \\
Shiraz & $10 \pm 0.08$ & $15 \pm 0.10$ & $31.9 \pm 0.31$ & $37 \pm 0.09$ \\
Varamin & $9.9 \pm 0.33$ & $20.5 \pm 0.35$ & $35 \pm 0.17$ & $40.1 \pm 0.18$ \\
\hline
\end{tabular}

\subsection{Germination Time}

Under the temperature of $15{ }^{\circ} \mathrm{C}$, Gorgan landrace seeds did not reach $50 \%$ of germination; thus, the time to $50 \%$ germination (D50) at $15^{\circ} \mathrm{C}$ was not calculated and compared. The D50 was greatly affected by landrace $(\mathrm{F}=35.83, p<0.001)$, temperature $(\mathrm{F}=97.79$, $p<0.001)$ and the interactions of both parameters $(\mathrm{F}=78.66, p<0.001)$. For Esfarayen, Gorgan, Sari, Shiraz, and Varamin landraces, the minimum D50 was observed at the temperature of $30{ }^{\circ} \mathrm{C}$, and the corresponding D50 was $54,22,25,41$, and $23 \mathrm{~h}$, respectively (Figure 2), while for the Rasht landrace, the lowest D50 was obtained at the temperature of $25^{\circ} \mathrm{C}(43 \mathrm{~h}$ ) (Figure 2). Seeds of landraces germinated slowly under lower temperature regimes $\left(15\right.$ or $\left.20^{\circ} \mathrm{C}\right)$ but accelerated greatly when incubation temperature increased. For example, in Varamin landrace, D50 was reduced by $72,81,87$, and $12 \%$ when the temperature increased from 15 to $35^{\circ} \mathrm{C}$ relative to $30^{\circ} \mathrm{C}$ (Figure 2).

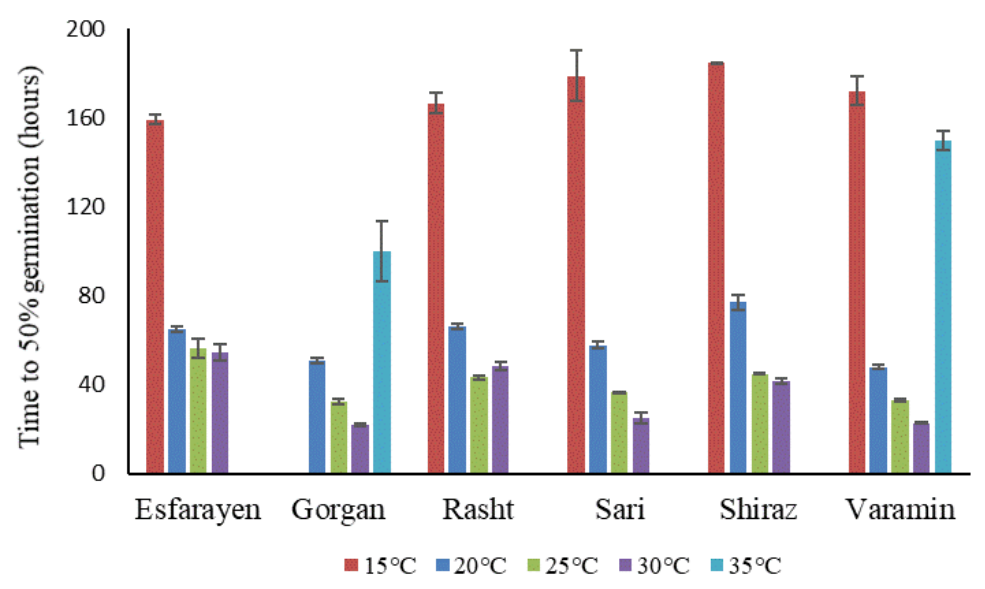

Figure 2. Time to 50\% germination (D50; hours) with standard error for six tomato landraces (Esfarayen, Gorgan, Rasht, Sari, Shiraz, and Varamin) under different temperature regimes (15, 20, 25, 30 , and $\left.35^{\circ} \mathrm{C}\right)$.

\subsection{Germination Rate}

The inverse of the time required for the germination process corresponds to the rate of germination. The germination rate is described mathematically using a segmented function that fits the measured germination rate data (Figure 3; Table 3). The intersection of the two regression lines indicates the maximum germination rate and optimum temperature. The maximum germination rate (Rmax) varied from 0.0248 to $0.0461 \mathrm{~h}^{-1}$, the inverse of 40.3 to $21.7 \mathrm{~h}$, among different landraces. The values of Rmax occurred at temperatures of $27.2-30.9^{\circ} \mathrm{C}$, the so-called optimum temperature $\left(T_{o}\right)$. The intersections of regression lines with the x-axis indicated the $T_{b}$ and $T_{c}$ at which the rate germination is zero. The germination rate increased linearly at temperatures between $T_{b}$ and $T_{o}$ and decreased linearly at temperatures between $T_{o}$ and $T_{c}$ for all landraces (Figure 3 ). The value of $T_{b}$ was estimated from 10.3 to $11.9^{\circ} \mathrm{C}$ among the landraces. The value of $T_{c}$ was fixed at $36{ }^{\circ} \mathrm{C}$ for all landraces. We found no statistically significant difference among values of $T_{b}$, and 
also, there was no significant difference among values of $T_{0}$, although there were small variations in both $T_{b}$ and to values.
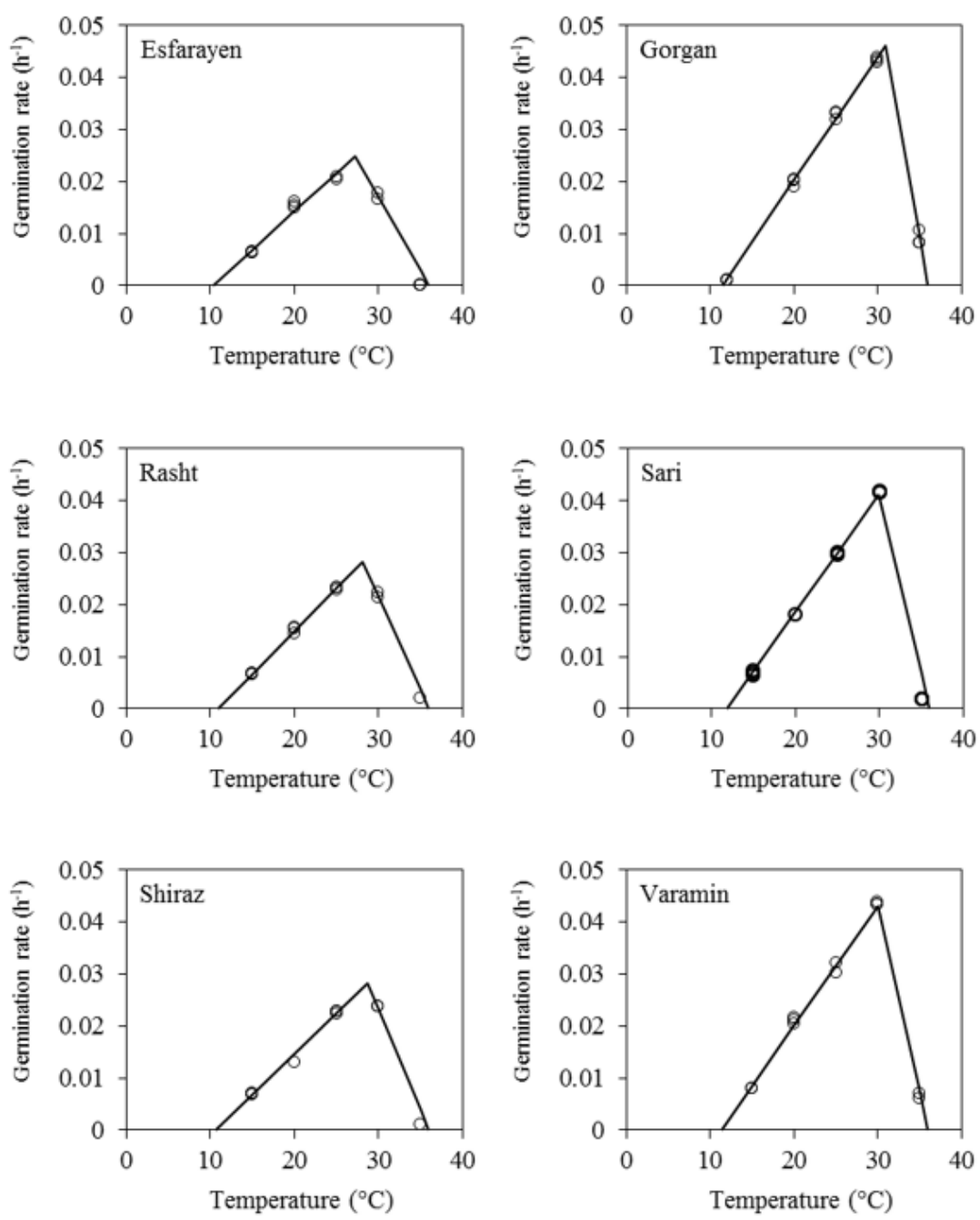

Figure 3. Relations between the germination rate and temperature for six tomato landraces (Esfarayen, Gorgan, Rasht, Sari, Shiraz, and Varamin). The lines indicate the drawn segmented function based on function parameter estimates shown in Table 3.

Table 3. Estimates $( \pm \mathrm{SE})$ of base temperature $\left(T_{b},{ }^{\circ} \mathrm{C}\right)$, optimum temperature $\left(T_{o},{ }^{\circ} \mathrm{C}\right)$, maximum germination rate $\left(\mathrm{h}^{-1}\right)$, minimum time required for germination (Dmin, h) and thermal time (TT, ${ }^{\circ} \mathrm{C} \mathrm{d}^{-1}$ ) for germination of six tomato landraces using segmented function. The ceiling temperature $\left(T_{c},{ }^{\circ} \mathrm{C}\right)$ was considered fixed.

\begin{tabular}{ccccccc}
\hline Landrace & $\boldsymbol{T}_{\boldsymbol{b}} \pm \mathbf{S E}$ & $\boldsymbol{T}_{\boldsymbol{o}} \pm \mathbf{S E}$ & $\boldsymbol{T}_{\boldsymbol{c}}$ & $\mathbf{R m a x}$ & Dmin & TT \\
\hline Esfarayen & $10.3 \pm 0.99$ & $27.2 \pm 0.49$ & 36 & 0.0248 & 40.3 & 35.7 \\
Gorgan & $11.5 \pm 0.20$ & $30.9 \pm 0.23$ & 36 & 0.0461 & 21.7 & 15.7 \\
Rasht & $10.9 \pm 0.34$ & $28.1 \pm 0.15$ & 36 & 0.0284 & 35.2 & 24.3 \\
Sari & $11.9 \pm 0.89$ & $29.9 \pm 0.31$ & 36 & 0.0411 & 24.3 & 24.3 \\
Shiraz & $10.6 \pm 0.67$ & $28.7 \pm 0.26$ & 36 & 0.0282 & 35.5 & 24.7 \\
Varamin & $11.3 \pm 0.39$ & $30.0 \pm 0.12$ & 36 & 0.0437 & 23.0 & 16.8 \\
\hline
\end{tabular}

\subsection{Climate Change Scenarios}

As indicated in Figure 4, the baseline mean temperature during the sowing period varied from 17.7 to $18.6^{\circ} \mathrm{C}$ in studied locations. There is a temperature difference of $0.9^{\circ} \mathrm{C}$ 
among the locations. The lowest mean temperature of the sowing period was related to Esfarayen, and the highest mean temperature was for Sari (Figure 4).

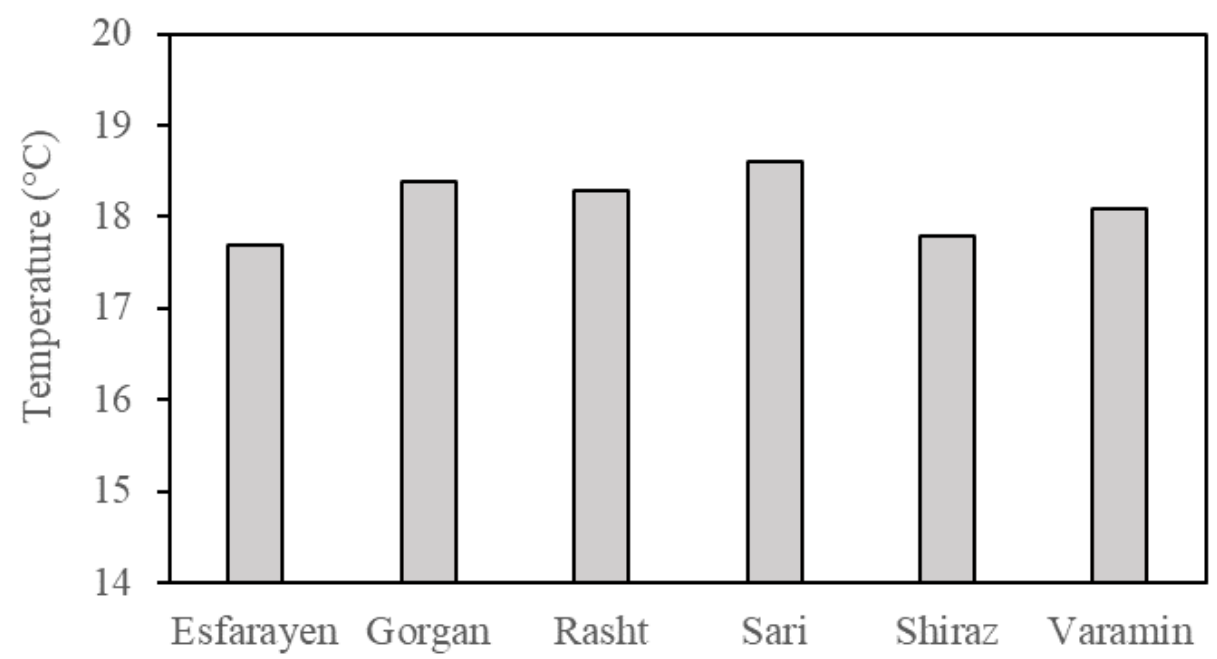

Figure 4. Mean temperature of sowing period across baseline period (1980-2009) for six locations (Esfarayen, Gorgan, Rasht, Sari, Shiraz, and Varamin).

Climatic scenario projections indicated that there would be an increase in mean temperature during the sowing period in both the near term and mid-term. The mean temperature is expected to increase from 0.8 to $1.3^{\circ} \mathrm{C}$ in the near term and 1.5 to $2.7^{\circ} \mathrm{C}$ in the mid-term under RCP 4.5 relative to the baseline (Figure 5). The temperature increase would be more severe under RCP 8.5, especially in the mid-term, with an increase of 0.9 to $1.9^{\circ} \mathrm{C}$ for the near term and 2.3 to $3.4{ }^{\circ} \mathrm{C}$ for the mid-term (Figure 5).

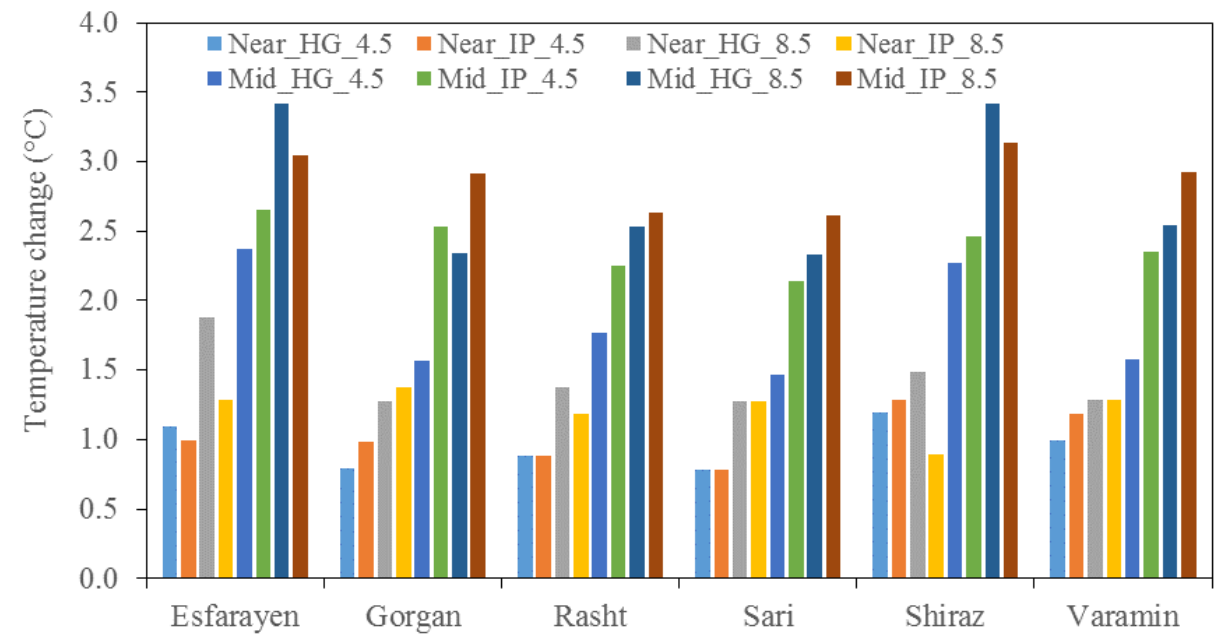

Figure 5. Change in mean temperature of sowing period in future climatic scenarios relative to baseline period (1980-2009) in six locations (Esfarayen, Gorgan, Rasht, Sari, Shiraz, and Varamin). Near, Near-term (2010-2039); Mid, Mid-term (2040-2069); HG, HadGEM; IP, IPSL; 4.5, RCP 4.5; 8.5, RCP 8.5.

It was found the variation in the derived-model projections for each location (Figure 5). The difference between derived-model projections of HadGEM and IPSL varied from -1.0 to $0.6{ }^{\circ} \mathrm{C}$. For example, the difference between HadGEM and IPSL model projections was $-0.2{ }^{\circ} \mathrm{C}$ for Varamin in the near term under RCP 4.5 that reached $0{ }^{\circ} \mathrm{C}$ under RCP 8.5. In contrast, the differences were -0.8 and $-0.4{ }^{\circ} \mathrm{C}$ in the mid-term under RCPs 4.5 and 8.5, respectively. Furthermore, there was no difference between HadGEM and IPSL projections 
in increasing temperature, such as projection in the near term under RCPs 4.5 and 8.5 for Sari and RCP 4.5 for Rasht.

\subsection{Effect of Future Climate on Germination}

The results showed that the FGP would not change in the future climate for Esfarayen, Rasht, Sari, and Shiraz under none of the climatic scenarios. However, the FGP increased up to $19.5 \%$ for Gorgan and $21.3 \%$ for Varamin under climatic scenarios relative to baseline. In the near term, FGP would be 85 to $90 \%$ for Gorgan and 81 to $84 \%$ for Varamin. With increasing the mean temperature in the mid-term, FGP would increase up to $92-97 \%$ for Gorgan and $86-94 \%$ for Varamin.

The time to germination would be decreased with increasing mean temperature under future climate conditions. Regarding the baseline mean temperature (Figure 4), it is estimated that the time to germination takes 2.5 to 3.8 days among the locations (Figure 6). The germination period would be 2.3 to 3.3 days for HadGEM and 2.2 to 3.4 days for IPSL in the near term under RCP 4.5. The germination duration will be shorter under RCP 8.5 and reach 2.1 to 3.1 days for HadGEM and 2.1 to 3.3 days for the IPSL model. For the mid-term and RCP 4.5, the germination time would be projected between 2.1 to 2.9 days under HadGEM and 1.9 to 2.8 days under IPSL model. Under RCP 8.5 , this would be 1.9 to 2.6 days for HadGEM model and 1.8 to 2.7 days for IPSL model.
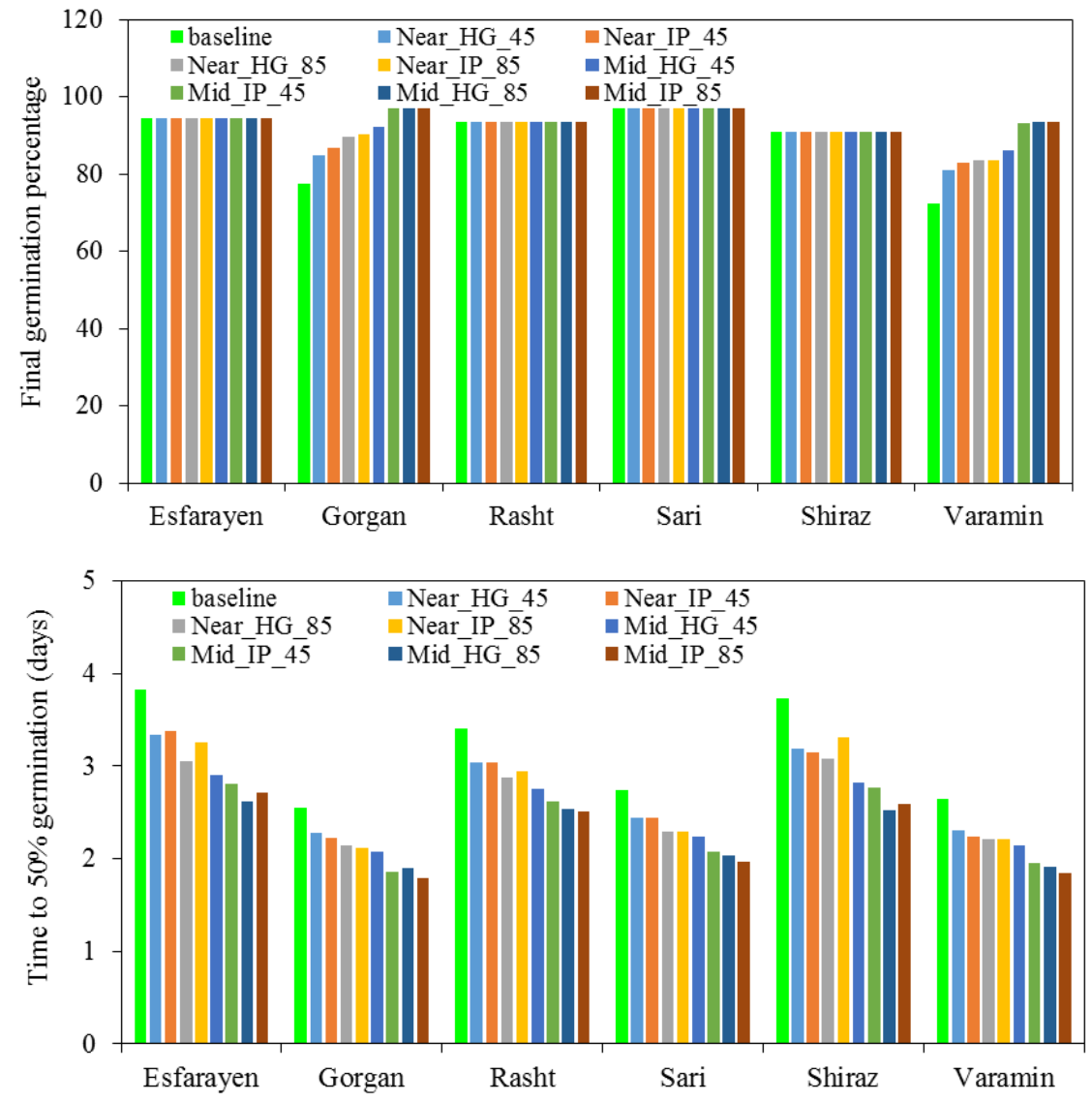

Figure 6. The value of FGP and D50 for six tomato landraces (Esfarayen, Gorgan, Rasht, Sari, Shiraz, and Varamin) under eight future climatic scenarios. Near, Near-term (2010-2039); Mid, Mid-term (2040-2069); HG, HadGEM; IP, IPSL; 4.5, RCP 4.5; 8.5, RCP 8.5.

\section{Discussion}

In the present study, FGP varied from 0 to $100 \%$ under temperatures between 10 and $40{ }^{\circ} \mathrm{C}$. Furthermore, the FGP was varied among the landraces. The germination in most landraces ceased at $37^{\circ} \mathrm{C}$, while at this temperature, the germination percentage was $32 \%$ 
for Gorgan and $60 \%$ for Varamin, which shows their adaptation to high temperatures. Similarly, Calzada-López et al. [43] indicated that the FGP values varied among different tomato cultivars. They showed that germination percentage was negligible at temperatures of 7-9 ${ }^{\circ} \mathrm{C}$ and $45^{\circ} \mathrm{C}$. The required temperatures $\left(15-30{ }^{\circ} \mathrm{C}\right)$ to reach the highest FGP in the present study are partly similar to values $\left(15-35^{\circ} \mathrm{C}\right)$ reported by Calzada-López et al. [43]. Furthermore, this is in agreement with the findings of Bidgoly et al. [32] and Zaferanieh et al. [19].

The estimate of cardinal temperatures $\left(10.3-11.9,27.2-30.9\right.$, and $\left.36{ }^{\circ} \mathrm{C}\right)$ in the present study was within the range reported for most developmental stages of tropical crops $[14,44]$. The $T_{b}$ values varied among landraces with a range of only $1.6{ }^{\circ} \mathrm{C}$ (Table 2 ). However, the $T_{b}$ values are similar to $T_{b}$ of $12-13.5^{\circ} \mathrm{C}$ reported for other tomato cultivars by Cheng and Bradford [45], 6-10 ${ }^{\circ} \mathrm{C}$ by Jones [46], and 7.7-9.9 ${ }^{\circ} \mathrm{C}$ by Sousaraei et al. [47]. The optimum and ceiling temperatures estimated in the present study were consistent with an optimum temperature of $25.5-29.5^{\circ} \mathrm{C}$, and the ceiling temperature of $35^{\circ} \mathrm{C}$ was reported for tomatoes [48]. Overall, the results obtained indicated that the time to germination onset increased as the temperature was away from the optimum temperature. The variation in FGP, CT and D50 in this study could also be attributed to the seed genetic diversity [49], the nutritional condition of the seeds on parental plants, and the environmental condition of seed production [50,51]. These factors probably change the biological processes in seed, such as water absorption or activity of enzymes or hormones [52]. Toh et al. [53] and Essemine et al. [54] have demonstrated that seed germination is inhibited with an increase in temperature through the induction of ABA. At high temperatures, the germination rate is strictly prohibited and causes cell death and embryos, for which the seedling establishment rate is also reduced [55].

This study shows that increasing temperature in the future plays an important impact in the germination process in the analyzed landraces and will lead to a decrease in the germination duration. The most important findings of the present study are that the FGP and D50 of landraces varied with increasing temperature in the future climatic condition. Contrary to the expectations [56,57], the temperature increase in future climatic scenarios did not change FGP, except for Gorgan and Varamin landraces. The increase in FGP for Gorgan and Varamin was due to approaching future temperatures to the optimum temperature for FGP in these landraces $\left(20.5^{\circ} \mathrm{C}\right)$. In other landraces, the projected temperature in future climatic scenarios placed on the range of optimal temperature for FGP; thus, it was not observed any changes in FGP under the future climatic scenarios. Furthermore, it was shown that the D50 decreased as the temperature in the future climatic scenarios approached the optimum temperature for germination rate in all landraces; 27 to $31{ }^{\circ} \mathrm{C}$ depending on the landrace. Milbau et al. [58] observed that an increase in temperature $\left(+2.5^{\circ} \mathrm{C}\right)$ strongly reduced the germination duration, while FGP did not change. Similarly, Duarte et al. [5] showed that the time required to sum thermal time to germinate was reduced under the warming scenarios, but the probability of persistence was decreased for Racinaea aerisincola in the rupestrian grasslands due to its limited seed germination window.

Chhetri and Rawal [59] showed that generally, temperature rise across the hot tropical areas might result in greater vulnerability in species germination and establishment than the warm and cooler areas. For example, low establishment potential and failure for most of the species under the future climatic condition across hotter regions such as Dumkauli (a region in Nepal) and Rampur (a region in India) suggest that these regions may become more vulnerable to climate change in the future. Dumkauli and Rampur have higher temperature conditions than the other study regions, and high-temperature conditions leading to increased evaporation can make the soil conditions dry, consequently affecting species establishment and physiological activities [60,61].

In the present study, variations in FGP and D50 probably demonstrated that germination requirements could change sowing dates for each landrace. This finding is in agreement with other researchers [29,62]. Sowing date adaptation is, by far, the most frequently investigated climate change adaptation option [63]. Of course, change in the 
sowing date requires further study of the effect of climate change on other developmental stages, growth, and yield. Van Ittersum and Rabbinge [64] indicated that the early sowing under future climate scenarios provides higher yield benefits. This is due to a prolonged vegetation period and a higher amount of intercepted solar radiation, as is the case for many field crops.

\section{Conclusions}

In general, it can conclude that global warming can result in rapid, uniform, and complete germination in different tomato landraces. However, to obtain the maximum yield, it is suggested to consider the impacts of global warming on different development and growth processes which lead to high yields by shortening the time from sowing to complete ground cover and allowing the establishment of optimum canopy structure to minimize inter-plant competition.

Author Contributions: K.M., B.T. and J.M. conceived the study; N.S. carried out the experiments and wrote the manuscript; N.S., B.T. and E.S. analyzed the data. All authors have read and agreed to the published version of the manuscript.

Funding: The research was funded by the Gorgan University of Agricultural Science and Natural Resource, Gorgan, Iran.

Institutional Review Board Statement: Not applicable.

Informed Consent Statement: Not applicable.

Data Availability Statement: The data presented in this study are available on request from the corresponding author.

Acknowledgments: The authors thanked the Gorgan University of Agricultural Sciences and Natural Resource, Iran, for providing research facilities and funds.

Conflicts of Interest: The authors declare no conflict of interest.

\section{References}

1. Chiang, G.C.; Bartsch, M.; Barua, D.; Nakabayashi, K.; Debieu, M.; Kronholm, I.; Koornneef, M.; Soppe, W.J.; Donohue, K.; de Meaux, J. DOG1 expression is predicted by the seed-maturation environment and contributes to geographical variation in germination in Arabidopsis thaliana. Mol. Ecol. 2011, 20, 3336-3349. [CrossRef] [PubMed]

2. Pendergrass, A.G.; Knutti, R.; Lehner, F.; Deser, C.; Sanderson, B.M. Precipitation variability increases in a warmer climate. Sci. Rep. 2017, 7, 17966. [CrossRef] [PubMed]

3. Kjellström, E.; Nikulin, G.; Strandberg, G.; Christensen, O.B.; Jacob, D.; Keuler, K.; Lenderink, G.; van Meijgaard, E.; Schär, C.; Somot, S.; et al. European climate change at global mean temperature increases of 1.5 and $2{ }^{\circ} \mathrm{C}$ above pre-industrial conditions as simulated by the EURO-CORDEX regional climate models. Earth Syst. Dyn. Discuss. 2018, 9, 459-478. [CrossRef]

4. Piñar Fuentes, J.C.; Cano-Ortiz, A.; Musarella, C.M.; Quinto Canas, R.; Pinto Gomes, C.J.; Spampinato, G.; del Río, S.; Cano, E. Bioclimatology, structure, and conservation perspectives of Quercus pyrenaica, Acer opalus subsp. Granatensis, and Corylus avellana deciduous forests on Mediterranean bioclimate in the south-central part of the Iberian Peninsula. Sustainability 2019, 11, 6500. [CrossRef]

5. Duarte, A.A.; de Lemos Filho, J.P.; Marques, A.R. Seed germination of bromeliad species from the campo rupestre: Thermal time requirements and response under predicted climate-change scenarios. Flora 2018, 238, 119-128. [CrossRef]

6. Zogas, A.; Kosman, E.; Sternberg, M. Germination strategies under climate change scenarios along an aridity gradient. J. Plant Ecol. 2020, 13, 470-477. [CrossRef]

7. Frate, L.; Carranza, M.L.; Evangelista, A.; Stinca, A.; Joop, H.J.; Schaminée, J.H.J.; Stanisci, A. Climate and land use change impacts on Mediterranean high-mountain vegetation in the Apennines since the 1950s. Plant Ecol. Plant Ecol. Divers. 2018, 11, 85-96. [CrossRef]

8. Jiménez, S.; Fattahi, M.; Bedis, K.; Nasrolahpour-moghadam, S.; Irigoyen, J.J.; Gogorcena, Y. Interactional effects of climate change factors on the water status, photosynthetic rate, and metabolic regulation in peach. Front. Plant Sci. 2020, 11, 43. [CrossRef]

9. Lobell, D.B.; Burke, M.B.; Tebaldi, C.; Mastrandrea, M.D.; Falcon, W.P.; Naylor, R.L. Prioritizing climate change adaptation needs for food security in 2030. Science 2008, 319, 607-610. [CrossRef]

10. Raza, A.; Razzaq, A.; Mehmood, S.S.; Zou, X.; Zhang, X.; Lv, Y.; Xu, J. Impact of climate change on crops adaptation and strategies to tackle its outcome: A review. Plants 2019, 8, 34. [CrossRef] 
11. Dantas, B.F.; Moura, M.S.; Pelacani, C.R.; Angelotti, F.; Taura, T.A.; Oliveira, G.M.; Bispo, J.S.; Matias, J.R.; Silva, F.F.; Pritchard, H.W.; et al. Rainfall, not soil temperature, will limit the seed germination of dry forest species with climate change. Oecologia 2020, 192, 529-541. [CrossRef] [PubMed]

12. Villalobos, A.; Campbell, R.; Díaz, R.; Martínez, J.; Escalante, D.; Martínez-Montero, M.E.; Quintana, N.; Yabor, L.; Höfer, M.; Lorenzo, J.C. Chickpea seed cryostorage alters germinant but not adult plant growth. Biologia 2020, 76, 55-61. [CrossRef]

13. Mahmood, A.H.; Florentine, S.K.; Chauhan, B.S.; McLaren, D.A.; Palmer, G.C.; Wright, W. Influence of various environmental factors on seed germination and seedling emergence of a noxious environmental weed: Green galenia (Galenia pubescens). Weed Sci. 2016, 64, 486-494. [CrossRef]

14. Torabi, B.; Attarzadeh, M.; Soltani, A. Germination response to temperature in different safflower (Carthamus tinctorius) cultivars. Seed Technol. 2013, 35, 47-59. Available online: https://www.jstor.org/stable/24642240 (accessed on 6 January 2022).

15. Soltani, E.; Baskin, C.C.; Baskin, J.M. A graphical method for identifying the six types of non-deep physiological dormancy in seeds. Plant Biol. 2017, 19, 673-682. [CrossRef]

16. Moghaddam, P.R.; Feizi, H.; Mondani, F. Evaluation of tomato production systems in terms of energy use efficiency and economical analysis in Iran. Not. Sci. Biol. 2011, 3, 58-65. [CrossRef]

17. Sacco, A.; Ruggieri, V.; Parisi, M.; Festa, G.; Rigano, M.M.; Picarella, M.E.; Mazzucato, A.; Barone, A. Exploring a tomato landraces collection for fruit-related traits by the aid of a high-throughput genomic platform. PLoS ONE 2015, 10, e0137139. [CrossRef]

18. Torabi, B.; Archontoulis, S.V.; Hoogenboom, G. A new function for prediction of biological processes response to temperature. Int. J. Plant Prod. 2020, 14, 9-22. [CrossRef]

19. Zaferanieh, M.; Mahdavi, B.; Torabi, B. Effect of temperature and water potential on Alyssum homolocarpum seed germination: Quantification of the cardinal temperatures and using hydrothermal time. S. Afr. J. Bot. 2020, 131, 259-266. [CrossRef]

20. Yvon-Durocher, G.; Schaum, C.E.; Trimmer, M. The temperature dependence of phytoplankton stoichiometry: Investigating the roles of species sorting and local adaptation. Front. Microbiol. 2017, 8, 2003. [CrossRef]

21. Aguirre-Liguori, J.A.; Gaut, B.S.; Jaramillo-Correa, J.P.; Tenaillon, M.I.; Montes-Hernández, S.; García-Oliva, F.; Hearne, S.J.; Eguiarte, L.E. Divergence with gene flow is driven by local adaptation to temperature and soil phosphorus concentration in teosinte subspecies (Zea mays parviglumis and Zea mays mexicana). Mol. Ecol. 2019, 28, 2814-2830. [CrossRef] [PubMed]

22. Fernández-Pascual, E.; Jiménez-Alfaro, B. Phenotypic plasticity in seed germination relates differentially to overwintering and flowering temperatures. Seed Sci. Res. 2014, 24, 273. [CrossRef]

23. Noble, D.W.; Stenhouse, V.; Schwanz, L.E. Developmental temperatures and phenotypic plasticity in reptiles: A systematic review and meta-analysis. Biol. Rev. 2018, 93, 72-97. [CrossRef] [PubMed]

24. Arnold, P.A.; Nicotra, A.B.; Kruuk, L.E. Sparse evidence for selection on phenotypic plasticity in response to temperature. Philos. Trans. R. Soc. B 2019, 374, 20180185. [CrossRef]

25. Fasih, M.; Afshari, R.T. The morphophysiological dormancy of Ferula ovina seeds is alleviated by low temperature and hydrogen peroxide. Seed Sci. Res. 2018, 28, 52. [CrossRef]

26. Bafoil, M.; Jemmat, A.; Martinez, Y.; Merbahi, N.; Eichwald, O.; Dunand, C.; Yousfi, M. Effects of low temperature plasmas and plasma activated waters on Arabidopsis thaliana germination and growth. PLoS ONE 2018, 13, e0195512. [CrossRef]

27. Perrino, E.V.; Wagensommer, R.P. Crop wild relatives (CWR) priority in Italy: Distribution, ecology, in situ and ex situ conservation and expected actions. Sustainability 2021, 13, 1682. [CrossRef]

28. Donohue, K.; Dorn, L.; Griffith, C.; Kim, E.; Aguilera, A.; Polisetty, C.R.; Schmitt, J. The evolutionary ecology of seed germination of Arabidopsis thaliana: Variable natural selection on germination timing. Evolution 2005, 59, 758-770. [CrossRef]

29. Liu, X.; Xu, D.; Yang, Z.; Zhang, N. Geographic variations in seed germination of Dalbergia odorifera T. Chen in response to temperature. Ind. Crops Prod. 2017, 102, 45-50. [CrossRef]

30. Yuan, X.; Wen, B. Seed germination response to high temperature and water stress in three invasive Asteraceae weeds from Xishuangbanna, SW China. PLoS ONE 2018, 13, e0191710. [CrossRef]

31. Mobli, A.; Mijani, S.; Ghanbari, A.; Rastgoo, M. Seed germination and emergence of two flax-leaf alyssum (Alyssum linifolium Steph. ex. Willd.) populations in response to environmental factors. Crop Pasture Sci. 2019, 70, 807-813. [CrossRef]

32. Bidgoly, R.O.; Balouchi, H.; Soltani, E.; Moradi, A. Effect of temperature and water potential on Carthamus tinctorius L. seed germination: Quantification of the cardinal temperatures and modeling using hydrothermal time. Ind. Crops Prod. 2018, 113, 21-127. [CrossRef]

33. Hoogenboom, G.; Porter, C.H.; Shelia, V.; Boote, K.J.; Singh, U.; White, J.W.; Hunt, L.A.; Ogoshi, R.; Lizaso, J.I.; Koo, J.; et al. Decision Support System for Agrotechnology Transfer (DSSAT); Version 4.7.5.; DSSAT Foundation: Gainesville, FL, USA, 2019; Available online: https:/ / DSSAT.net (accessed on 6 January 2022).

34. Gudmundsson, S.V.; Anger, A. Global carbon dioxide emissions scenarios for aviation derived from IPCC storylines: A metaanalysis. Transp. Res. D Transp. Environ. 2012, 17, 61-65. [CrossRef]

35. Hawkins, E.; Ortega, P.; Suckling, E.; Schurer, A.; Hegerl, G.; Jones, P.; Joshi, M.; Osborn, T.J.; Masson-Delmotte, V.; Mignot, J.; et al. Estimating changes in global temperature since the preindustrial period. Bull. Am. Meteorol. Soc. 2017, 98, 1841-1856. [CrossRef]

36. Van Vuuren, D.P.; Edmonds, J.A.; Kainuma, M.; Riahi, K.; Weyant, J. A special issue on the RCPs. Clim. Change 2011, $109,1$. [CrossRef]

37. Thomson, A.M.; Calvin, K.V.; Smith, S.J.; Kyle, G.P.; Volke, A.; Patel, P.; Delgado-Arias, S.; Bond-Lamberty, B.; Wise, M.A.; Clarke, L.E.; et al. RCP4.5: A pathway for stabilization of radiative forcing by 2100. Clim. Change 2011, 109, 77. [CrossRef] 
38. Riahi, K.; Rao, S.; Krey, V.; Cho, C.; Chirkov, V.; Fischer, G.; Kindermann, G.; Nakicenovic, N.; Rafaj, P. RCP 8.5-A scenario of comparatively high greenhouse gas emissions. Clim. Change 2011, 109, 33. [CrossRef]

39. Hudson, N.; Ruane, A.C. Guide for Running AgMIP Climate Scenario Generation Tools with R in Windows, Version 2.3. Appendix 2. 2013. Available online: https:/ /ntrs.nasa.gov/citations/20150007687 (accessed on 6 January 2022).

40. Rosenzweig, C.; Jones, J.W.; Hatfield, J.L.; Ruane, A.C.; Boote, K.J.; Thorburn, P.; Antle, J.M.; Nelson, G.C.; Porter, C.; Janssen, S.; et al. The agricultural model intercomparison and improvement project (AgMIP): Protocols and pilot studies. Agric. Meteorol. 2013, 170, 166-182. [CrossRef]

41. Rosenzweig, C.; Hillel, D. Handbook of Climate Change and Agroecosystems: The Agricultural Model Intercomparison and Improvement Project (AgMIP) Integrated Crop and Economic Assessments—Joint Publication with American Society of Agronomy, Crop Science Society of America, and Soil Science Society of America (In 2 Parts); Imperial College Press: London, UK, 2015.

42. Hatami, E.; Raeini Sarjaz, M.; Chalavi, V. Evaluation of the thermal and humidity relations and cucumber yield within plastic tunnel microclimates. J. Agric. Meteorol. 2013, 1, 26-36.

43. Calzada López, S.G.; Shibata, J.K.; Uscanga Mortera, E.; García Esteva, A.; Yáñez Jiménez, P. Cardinal temperatures and germination rate in husk tomato cultivars. Rev. Mex. De Cienc. Agrícolas 2014, 8, 1451-1458.

44. Saberali, S.F.; Shirmohamadi-Aliakbarkhani, Z. Quantifying seed germination response of melon (Cucumis melo L.) to temperature and water potential: Thermal time, hydrotime and hydrothermal time models. S. Afr. J. Bot. 2020, 130, 240-249. [CrossRef]

45. Cheng, Z.Y.; Bradford, K.J. Hydrothermal time analysis of tomato seed germination responses to priming treatments. J. Exp. Bot. 1999, 50, 89-99. [CrossRef]

46. Jones, J.B. Instructions for Growing Tomatoes in the Garden and Green-House; GroSystems: Anderson, SC, USA, 2013.

47. Sousaraei, N.; Torabi, B.; Mashaiekhi, K.; Soltani, E.; Mousavizadeh, S.J. Variation of seed germination response to temperature in tomato landraces: An adaptation strategy to environmental conditions. Sci. Hort. 2021, 281, 109987. [CrossRef]

48. Labouriau, L.G.; Osborn, J.H. Temperature dependence of the germination of tomato seeds. J. Therm. Biol. 1984, 9, 285-294. [CrossRef]

49. Finch-Savage, W.E.; Bassel, G.W. Seed vigour and crop establishment: Extending performance beyond adaptation. J. Exp. Bot. 2016, 67, 567-591. [CrossRef]

50. Brzezinski, C.R.; Abati, J.; Henning, F.A.; Henning, A.A.; França Neto, J.D.B.; Krzyzanowski, F.C.; Zucareli, C. Spray volumes in the industrial treatment on the physiological quality of soybean seeds with different levels of vigor. Res. J. Seed Sci. 2017, 39, 174-181. [CrossRef]

51. Silva, A.S.; Schmid, L.P.; Mielezrski, F.; Pavan, B.E. Physiological quality of rice seeds stored in different environments and packages. J. Exp. Agric. Int. 2018, 23, 1-9. [CrossRef]

52. Torabi, B.; Soltani, E.; Archontoulis, S.V.; Rabii, A. Temperature and water potential effects on Carthamus tinctorius L. seed germination: Measurements and modeling using hydrothermal and multiplicative approaches. Rev. Bras. Bot. 2016, 39, 427-436. [CrossRef]

53. Toh, S.; Imamura, A.; Watanabe, A.; Nakabayashi, K.; Okamoto, M.; Jikumaru, Y.; Hanada, A.; Aso, Y.; Ishiyama, K.; Tamura, N.; et al. High temperature-induced abscisic acid biosynthesis and its role in the inhibition of gibberellin action in Arabidopsis seeds. Plant Physiol. 2008, 146, 1368-1385. [CrossRef]

54. Essemine, J.; Ammar, S.; Bouzid, S. Impact of heat stress on germination and growth in higher plants: Physiological, biochemical and molecular repercussions and mechanisms of defense. J. Biol. Sci. 2010, 10, 565-572. [CrossRef]

55. Cheng, L.; Zou, Y.; Ding, S.; Zhang, J.; Yu, X.; Cao, J.; Lu, G. Polyamine accumulation in transgenic tomato enhances the tolerance to high temperatures stress. J. Integr. Plant Biol. 2009, 51, 489-499. [CrossRef] [PubMed]

56. Graae, B.J.; Alsos, I.G.; Ejrnaes, R. The impact of temperature regimes on development, dormancy breaking and germination of dwarf shrub seeds from arctic, alpine and boreal sites. Plant Ecol. 2008, 198, 275-284. [CrossRef]

57. Kildisheva, O.A.; Dixon, K.W.; Silveira, F.A.; Chapman, T.; Di Sacco, A.; Mondoni, A.; Turner, S.R.; Cross, A.T. Dormancy and germination: Making every seed count in restoration. Restor. Ecol. 2020, 28, S256-S265. [CrossRef]

58. Milbau, A.; Graae, B.J.; Shevtsova, A.; Nijs, I. Effects of a warmer climate on seed germination in the subarctic. Ann. Bot. 2009, 104, 287-296. [CrossRef]

59. Chhetri, S.B.; Rawal, D.S. Germination phenological response identifies flora risk to climate change. Climate 2017, 5, 73. [CrossRef]

60. Fennessey, N.M.; Kirshen, P.H. Evaporation and evapo-transpiration under climate change in New England. J. Water Res. Plan. Manag. 1994, 120, 48-69. [CrossRef]

61. Falloon, P.; Betts, R. Climate impacts on European agriculture and water management in the context of adaptation and mitigationThe importance of an integrated approach. Sci. Total Environ. 2010, 408, 5667-5687. [CrossRef]

62. Abe, T.; Matsunaga, M. Geographic variation in germination traits in Melia azedarach and Rhaphiolepis umbellata. Am. J. Plant Sci. 2011, 2, 52-55. [CrossRef]

63. White, J.W.; Hoogenboom, G.; Kimball, B.A.; Wall, G.W. Methodologies for simulating impacts of climate change on crop production. Field Crop Res. 2011, 124, 357-368. [CrossRef]

64. Van Ittersum, M.K.; Rabbinge, R. Concepts in production ecology for analysis and quantification of agricultural input-output combinations. Field Crop Res. 1997, 52, 197-208. [CrossRef] 